\title{
Analisis Kualitas Layanan Program Praktek Kerja Lapangan (PKL) Mahasiswa Jurusan Tata Boga Politeknik Negeri Balikpapan Tahun 2015
}

\author{
Syahrul Karim ${ }^{1)}$, Yogiana Mulyani ${ }^{2)}$ Tuatul Mahfud $^{3)}$ \\ Jurusan Tata Boga \\ Politeknik Negeri Balikpapan \\ Jl. Soekarno Hatta Km.8 Balikpapan \\ Email : syahrul.karim@poltekba.ac.id, yogina.mulyani@poltekba.ac.id, tutaul.mahfud@poltekba.ac.id
}

\begin{abstract}
Abstrack
Balikpapan East Kalimantan as an economic barometer Kalimantan even continue to grow especially in the sector of tourism support the hospitality industry. End of 2015, the number of hotels in Balikpapan 75 units. This figure rose to 80 units in 2016. (Disporabudpar Balikpapan, 2015). Hotel presence contributes directly to employment. Not only Balikpapan, but a number of cities in East Kalimantan even outside of Borneo, such as Java and Sulawesi. State Polytechnic Balikpapan is the only campus in Kalimantan, which organizes lectures majoring in culinary Diploma III. Every year 40 students graduated / I since 2013. One of the flagship program of the Department of cookery is the delivery service Job Training (PKL) in the hospitality industry, catering and restaurant for six months. PKL service student success cookery State Polytechnic Balikpapan should be measured by various indicators of services during the performance management vendors by involving the industry as a user of the service. From the results of recent research shows that the quality of student services PKL majors Catering, Polytechnic of Balikpapan in 2015 rated satisfactory by the street vendors (the hotel industry and catering) for the nine attributes of service that is dependability, attitude, personality, quantity, adaptability, quality, Job Knowledge and grooming has average ratings of at least 3.2 (in the satisfactory category). While three other service attributes attendance, initiative, and discipline unsatisfactory. Has a sufficiently low value or below 3.2 (in the satisfactory category). This is in line with the IPA matrix analysis results where there are four elements that are considered important by the hotel management but did not provide the satisfaction of attendance, Initiative, discipline and job knowledge.
\end{abstract}

Key Words :service attributes, trainee, expectations, satisfaction

\begin{abstract}
Abstrak
Balikpapan sebagai barometer ekonomi Kalimatan Timur bahkan Kalimantan terus tumbuh terutama di sektor industry pendukung pariwisata yakni perhotelan. Akhir tahun 2015, jumlah hotel di Balikpapan 75 unit. Angka ini naik menjadi 80 unit di tahun 2016. (Disporabudpar Balikpapan, 2015). Keberadaan hotel memberikan andil secara langsung terhadap penyerapan tenaga kerja. Tidak hanya Balikpapan, namun sejumlah kota di Kaltim bahkan di luar Kalimantan, seperti Jawa dan Sulawesi. Politeknik Negeri Balikpapan merupakan satu satunya kampus di Kalimantan yang menyelenggarakan perkuliahan jurusan tata boga Diploma III. Setiap tahun meluluskan 40 mahasiswa/I sejak tahun 2013. Salah satu program unggulan dari jurusan tata boga adalah penyelenggaran layanan Praktek Kerja Lapangan (PKL) di industry perhotelan, catering dan restaurant selama enam bulan. Keberhasilan layanan PKL mahasiswa/I tata boga Politeknik Negeri Balikpapan harus diukur dengan berbagai indicator layanan selama melaksanakan PKL dengan melibatkan management industry sebagai pengguna layanan. Dari hasil penelian menunjukan bahwa kualitas layanan mahasiswa PKL jurusan Tata Boga, Politeknik Negeri Balikpapan 2015 dinilai memuaskan oleh pengguna PKL (industri hotel dan catering) untuk 9 atribut layanan yakni dependability, attitude, personality, quantity, adaptability, quality, Job Knowledge dan grooming yang memiliki rata rata penilaian minimal 3.2 (dalam kategori memuaskan). Sedangkan 3 atribut layanan lainnya attendance, iniciative, dan discipline kurang memuaskan. Memiliki nilai yang cukup rendah atau dibawah 3.2 (dalam kategori memuaskan). Ini sejalan dengan hasil analisi matrix IPA dimana terdapat empat element yang dianggap penting oleh managemen hotel namun belum memberikan kepuasan yakni attendance, iniciative, discipline dan job knowledge.
\end{abstract}

Kata Kunci : kualitas layanan, praktek kerja lapangan, harapan, kepuasan 


\section{Pendahuluan}

Balikpapan sebagai barometer ekonomi Kalimatan Timur bahkan Kalimantan terus tumbuh terutama di sektor industry pendukung pariwisata yakni perhotelan. Akhir tahun 2015, jumlah hotel di Balikpapan 75 unit. Angka ini naik menjadi 80 unit di tahun 2016. (Disporabudpar Balikpapan, 2015). Ketersediaan industry perhotelan selaras dengan penetapan Balikpapan sebagai kota MICE di Indonesia. Kendati masih berada diurutan 13. Jakarta dan Bali berada di urutan teratas. (Pusat Studi MICE PNJ, 2014).

Keberadaan hotel memberikan andil secara langsung terhadap penyerapan tenaga kerja. Tidak hanya Balikpapan, namun sejumlah kota di Kaltim bahkan di luar Kalimantan, seperti Jawa dan Sulawesi.

Politeknik Negeri Balikpapan merupakan satu satunya kampus di Kalimantan yang menyelenggarakan perkuliahan Jurusan Tata Boga Diploma III. Setiap tahun meluluskan 40 mahasiswa/I sejak tahun 2013. Lulusan ini terserap di dunia industry perhotelan, jasa restauran dan catering. Sebagian memilih berwirausaha. System perkuliahan yang diterapkan hampir sama dengan kampus lainya yang menyelenggarakan styudi DIII, dimana komposisi praktek dengan teori sebanyak $60: 30$.

Salah satu program unggulan dari Jurusan Tata Boga adalah penyelenggaran layanan Praktek Kerja Lapangan (PKL) di industri perhotelan, catering dan restaurant selama enam bulan atau satu semester yang dilaksanakan di semester 5 tiap tahunnya. Program ini setara dengan jumlah 8 Sistem Kredit Semester (SKS) dan wajib diikuti setiap mahasiswa/i. Umumnya, mahasiswa/i jurusan tata boga Poltekba Balikpapan melaksanakan PKL di industri perhotelan di Departemen Food and Beverage Product. Program PKL menjadi tolak ukur keberhasilan penyelenggaraan pendidikan di kampus Politeknik Negeri Balikpapan - mahasiswa jurusan Tata Boga dalam mengaplikasikan secara langsung teori dan praktek sehingga pasca study diharapkan menjadi lulusan siap pakai di dunia industry dan dapat bersaing di tingkat global.

Keberhasilan layanan PKL mahasiswa/I jurusan Tata Boga Politeknik Negeri Balikpapan harus diukur dengan berbagai indikator layanan selama melaksanakan PKL di industri perhotelan dengan melibatkan management industri sebagai pengguna layanan untuk dijadikan acuan dalam bahan evaluasi sehingga kedepannya dapat ditingkatkan.

Berdasarkan latar belakang diatas, penelitian akan menfokuskan pada kualitas layanan PKL mahasiswa Tata Boga Politeknik Negeri Balikpapan Semester V yang telah melaksanakan PKL selama enam bulan mulai Juli hingga Desember 2015 didua kota, Balikpapan dan Bontang dengan jumlah 10 tempat. Adapun pertanyaan yang diajukan dalam penelitian ini adalah : (1) Sejauh mana element/atribut kualitas layanan PKL mahasiswa Jurusan Tata Boga Politeknik Negeri Balikpapan terhadap pengguna layanan; (2) Bagaimana kesesuaian kualitas layanan PKL mahasiswa Jurusan Tata Boga Politeknik Negeri Balikpapan secara keseluruan dalam memenuhi harapan dan kepuasaan pengguna layanan.

Menurut Kotler (1999), kepuasan adalah perasaan senang atau kecewa seseorang yang muncul setelah membandingkan antara persepsi atau kesan terhadap kinerja atau hasil suatu produk dan harapan-harapannya. Sementara layanan adalah sebuah aktivitas yang diasosiasikan dengan elemen intangibility (sesuatu yang abstrak), dimana di dalamnya terjadi interaksi antara pelanggan dengan penyedia layanan tetapi tidak berakibat terhadap suatu kepemilikan. Perubahan kondisi dapat saja terjadi dan produksi layanan bisa saja berkaitan dengan sebuah produk fisik. (Kotler \& Keller, 2006).

Ini tegaskan juga oleh Cristhoper (Tjandra, 2005) bahwa pelayanan dapat 
diartikan sebagai suatu sistem manajemen, diorganisir untuk menyediakan hubungan pelayanan yang berkesinambungan antara waktu pemesanan dan waktu barang atau jasa itu diterima dan digunakan dengan tujuan untuk memenuhi kebutuhan/harapan pelanggan dalam jangka panjang. Sedangkan kualitas layanan menurut Tjiptono (2001) dapat diketahui dengan cara membandingkan persepsi para konsumen atas pelayanan yang nyata-nyata mereka terima / peroleh dengan pelayanan yang sesungguhnya mereka harapkan/inginkan terhadap atribut-atribut pelayanan suatu perusahaan.

Pelayanan merupakan faktor sangat penting dan merupakan kunci sukses terutama bagi perusahaan yang bergerak dibidang jasa. Kualitas layanan harus menjadi fokus perhatian manajemen perusahaan untuk mendapatkan hasil maksimal atau unggul dengan perusahaan yang lain bergerak dibidang jasa makanan.

Kualitas pelayanan menurut J.Supranto (2006) adalah sebuah kata yang bagi penyedia jasa merupakan sesuatu yang harus dikerjakan dengan baik. Sedangkan menurut Gronroos (dalam Ratminto, 2005) adalah suatu aktivitas atau serangkaian aktivitas yang bersifat tidak kasat mata yang terjadi sebagai akibat adanya interaksi antara konsumen dengan karyawan atau hal-hal lain yang disediakan oleh perusahaan pemberi pelayanan yang dimaksud untuk memecahkan permasalahan konsumen / pelanggan.

Karyawan adalah setara dengan layanan.

Mereka memproduksi/menyediakan dan menyampaikan layanan secara langsung pada pelanggan. Mereka adalah wakil dari perusahaan yang berfungsi sebagai pemasar sehingga mereka dapat mempengaruhi kepuasan pelanggan. Lovelock \& Wirtz (2004) mengatakan bahwa frontline staffs/service employees mempunyai peranan yang sangat penting dalam mengantisipasi kebutuhankebutuhan pelanggan, menyesuaikan penyampaian layanan, dan membangun hubungan interpersonal dengan pelanggannya sehingga dapat meningkatkan kesetiaan pelanggan (customer loyalty). Untuk dapat bertindak profesional, karyawan harus memenuhi beberapa persyaratan berikut ini (Andreani, 2007); (1) Dependability (dapat dipercaya) ; Kepercayaan adalah dasar dari suatu hubungan yang mendasar (King Jr. \& Cichy, 2006). Dengan dasar kepercayaan yang kuat maka interaksi/hubungan antara karyawan dan pelanggan juga akan semakin erat (King Jr. \& Cichy, 2006, p.105-106); (2) Attendance (kehadiran); Kehadiran karyawan dalam proses layanan merupakan suatu keharusan karena proses ini melibatkan interaksi langsung antara karyawan sebagai penyedia layanan dengan pelanggan. Zeithaml \& Bitner (2003,) menyatakan interaksi ini bisa bersifat langsung (melalui tatap muka) maupun tak langsung (melalui telpon, internet, dsb); (3) Attitude (sikap); Karyawan harus berusaha untuk melayani pelanggan sebaik mungkin untuk dapat memenuhi apa yang diharapkan, diinginkan dan diperlukan oleh pelanggan (Rothman, 1991); (4)Personality (kepribadian); Riset yang dilakukan oleh Ekinci dan Riley menunjukkan bahwa personality (kepribadian) yang harmonis adalah penting dalam proses layanan karena hal ini akan mempengaruhi kualitas layanan yang diberikan karyawan sehingga dapat mempengaruhi kepuasan pelanggan (Harris \& Fleming, 2005); (5) Initiative (inisiatif); Karyawan harus punya inisiatif yang tinggi dalam mengantisipasi kebutuhan dan permintaan pelanggan serta mengatasi masalah/ konflik yang timbul dalam proses layanan (Lovelock \& Wirtz, 2004,);

Element selanjutnya (6) Quantity (hasil kerja); Peter Drucker menyatakan bahwa quantity menunjuk pada jumlah pekerjaan yang dihasilkan/ dikerjakan oleh karyawan,misalnya pekerjaan membersihkan dan menyiapkan kamar dan 
melayani sejumlah tamu (Zeithaml \& Bitner,2003,); (7) Adaptability (adaptasi dengan lingkungan); Karyawan harus mampu memberikan respon yang positif pada kebutuhan dan permintaan khusus dari pelanggan dalam proses layanan karena kualitas layanan karyawan dinilai berdasarkan fleksibilitasnya dalam merespon permintaan ini. Pelanggan akan merasa puas jika penyedia layanan berusaha mengakomodasi dan memenuhi kehendaknya (Zeithaml \& Bitner, 2003); (8) Discipline (disiplin); Karyawan taat pada kebijakan perusahaan dan tahu apa yang harus dilakukan dalam menghadapi keluhan pelanggan sesuai dengan aturan dan kebijakan perusahaan (Boella \& GossTurner, 2005,); (9) Quality (kualitas); Karyawan dituntut untuk bekerja secara efektif dan efisien. Mereka harus mampu meyampaikan layanan yang memuaskan pelanggannya dan pada saat yang sama mereka juga harus hemat dan produktif dengan apa yang mereka kerjakan (Zeithaml \& Bitner, 2003); (10) Job knowledge (pengetahuan atas pekerjaan) Karyawan mempunyai pengetahuan yang memadai atas layanan yang disampaikan selain memahami semua fase atas pekerjaan yang dilakukan (Boella \& GossTurner, 2005,);

Grooming(penampilan); Karyawan harus berpenampilan rapi dan bersih, cara karyawan memakai pakaian dan seragam serta dandanan yang dikenakan harus sesuai dengan suasana dan keadaan (Zeithaml \& Bitner, 2003, dan Gronroos, 2000,); (12) Leadership (kepemimpinan); Kepemimpinan memegang peranan yang sangat penting dalam proses layanan. Talenta ini diperlukan oleh semua orang dalam posisinya sebagai supervisor dan manajer (Lovelock \& Wirtz, 2004,); (13) Organizing (kemampuan mengorganisasikan pekerjaan); Sebagai seorang supervisor atau manajer, karyawan harus mampu merencanakan dan mengukur kinerja/kualitas layanan yang disampaikan agarsesuai dengan standard perusahaan. Jadi seorang pemimpin harus mempunyai ketrampilanmanajerial yang dapat memberikan kepuasanpelanggannya (Gronroos, 2000)

\section{Metode Penelitian}

Pendekatan penelitian yang digunakan dalam penelitian ini adalah deskriptif kualitatif yang bertujuan untuk mendekripsikan yang berlaku saat ini. Di dalamnya terdapat upaya mendeskripsikan, mencatat, analisis dan menginterpretasikan kondisi yang sekarang ini terjadi atau ada. Dengan kata lain penelitian deskriptif kualitatif ini bertujuan untuk memperoleh informasi-informasi mengenai keadaan yang ada. Pendekatan penelitian menggunakan Importance-Performance Analysis (IPA) dengan mean rating digunakan untuk menggambarkan seberapa jauh ke-11 atribut/elemen layanan sudah disampaikan oleh Mahasiswa Tata Boga Politeinik Negeri Balikpapan dalam program PKL di industry perhotelan salama enam bulan dari bulan Juli hingga Desember 2016. Kesebelas element kualitas layanan tersebut adalah (1) Dependability, (2) Attendance (3) Attitude (4)Personality (5) Initiative (6) Quantity (7) Adaptability(8) Discipline(9) Quality (10) Job knowledge (11) Grooming. Pemilihan 11 atribut karena dianggap mewakili kondisi mahasiswa yang melaksanakan PKL, sedangkan atribut leadership dan organizing tidak didapatkan mahasiswa selama melaksanakan PKL di industri perhotelan sehingga tidak dijadikan acuan dalam penilaian PKL.

Adapun Subjek penelitian atau responden dalam penelitian ini adalah industry hotel dan catering tempat mahasiswa Tata Boga melaksanakan PKL selama enam bulan Juli hingga Desember 2015. Sebanyak 9 hotel berada di Balikpapan dan 1 catering di Bontang.

\section{Pembahasan Hasil Penelitian}

Hasil keseluruan evelauasi mahasiswa PKL Jurusan Tata Boga, Politekinik Negeri Balikpapan tahun 2015 
di 10 tempat PKL, dapat dilihat pada table dibawah ini.

\begin{tabular}{|l|l|l|l|}
\hline No & $\begin{array}{l}\text { Atribut } \\
\text { Layanan }\end{array}$ & $\begin{array}{l}\text { Nilai } \\
\text { Penting }\end{array}$ & $\begin{array}{l}\text { Nilai } \\
\text { Kualitas }\end{array}$ \\
\hline 1 & Dependability & 3.9 & 3.5 \\
\hline 2 & Attendance & 4 & 3 \\
\hline 3 & Attitute & 3.9 & 3.5 \\
\hline 4 & Personality & 4.2 & 3.7 \\
\hline 5 & Iniciative & 4.1 & 2.9 \\
\hline 6 & Quantity & 3.9 & 3.3 \\
\hline 7 & Adaptability & 3.9 & 3.4 \\
\hline 8 & Discipline & 3.9 & 3 \\
\hline 9 & Quality & 4 & 3.2 \\
\hline 10 & Job Knowledge & 4.1 & 3.3 \\
\hline 11 & Grooming & 3.9 & 3.5 \\
\hline
\end{tabular}

Tabel 1 : Nilai rata rata (mean) management hotel terhadapkualitas layanan PKL Tata Boga 2015 (Sumber : Data Primer, diolah (2016)

Data di atas menunjukan bahwa kualitas layanan mahasiswa PKL jurusan Tata Boga, Politeknik Negeri Balikpapan 2015 sangat memuaskan untuk 9 atribut layanan yakni dependability, attitude, personality, Quantity, adaptability, Quality, Job Knowledge dan grooming yang memiliki rata rata penilaian minimal 3.2 (dalam kategori memuaskan). Sedangkan 3 atribut layanan lainnya attendance, iniciative, dan discipline kurang memuaskan. Memiliki nilai yang cukup rendah atau di bawah 3.2 (dalam kategori memuaskan).

Hasil Importance - PerformaAnalisis (IPA) mahasiswa PKL Tata Boga, Politeknik Negeri Balikpapan 2015

Analisis yang digunakan dalam penelitian ini adalah Importance dan Performance Analysis (IPA). Pengujian ini dilakukan untuk mengetahui penilaian management hotel terhadap mahasiswa Jurusan Tata Boga, Politeknik Negeri Balikpapan yang telah melaksanakan PKL selama enam bulan sehingga dapat diketahui kualitas dan kepentingan 11 indikator layanan. Ada pun hasil analisis dapat dilihat pada gambar berikut ini :

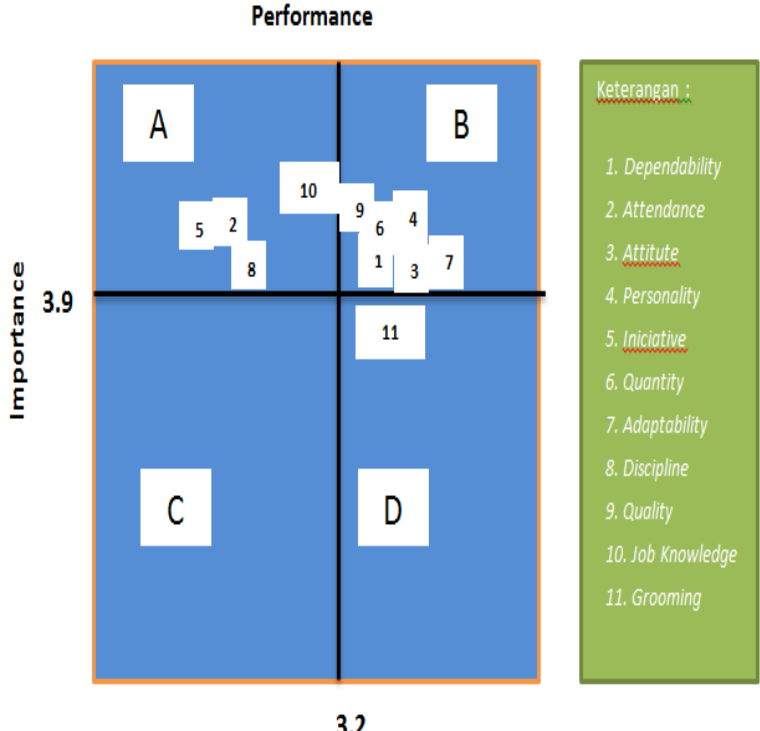

Gambar1 : Hasil analisis IPA layanan mahasiswa PKL Tata

Boga 2015 (Sumber : Hasil Analisis, 2016)

Hasil analisis matriks IPA di atas menunjukan bahwa : pada kuadran A (Concentrate here) ini memuat faktorfaktor yang dianggap penting oleh managemen hotel, tapi kenyataanya faktorfaktor ini belum sesuai harapan pelanggandalam hal ini pengguna PKL atau managemen hotel (tingkat kepuasan yang diperoleh masih rendah). Element element yang masuk kuadran ini harus ditingkatkan yakni Attendace. Kehadiran mahasiswa Tata Boga masih dianggap kurang oleh manangemen hotel secara keseluruan. Ada sebagian mahasiswa belum patuh pada aturan hotel terutama mengenai tingkat kehadiran. Padahal karyawan dalam proses layanan merupakan suatu keharusan karena proses ini melibatkan interaksi langsung antara karyawan sebagai penyedia layanan dengan pelanggan. (Zeithaml \& Bitner (2003).

Element selanjutnya yang masuk dalam kuadran A adalah initiative (inisiatif); mahasiswa Tata Boga Politeknik Negeri Balikpapan dianggap managemen hotel kurang inisiatif selama melaksanakan PKL. Ini dapat memberikan citra yang buruk bagi mahasiswa Politeknik Negeri Balikpapan dalam mencari pekerjaan. Inisiatif dapat memepercepat operasional kerja dalam 
memberikan pelayanan kepada pelanggan. Lovelock \& Wirtz, 2004, mengatakan karyawan harus punya inisiatif yang tinggi dalam mengantisipasi kebutuhan dan permintaan pelanggan serta mengatasi masalah/ konflik yang timbul dalam proses layanan.

Dicipline (disiplin) menurut John Macquarrie (1967) disiplin adalah suatu kemauan dan perbuatan seseorang dalam mematuhi seluruh peraturan yang telah terangkai dengan tujuan tertentu. Selama melaksanakan PKL di. hotel pengguna mahasiswa Tata Boga menilai tingkat disiplin mahasiswa Tata Boga cukup rendah terutama masalah disiplin waktu.

Sikap disiplin kerja karyawan sangat penting bagi suatu perusahaan dalam rangka mewujudkan suatu tujuan perusahaan, hal ini sesuai dengan penjelasan Malayu S.P Hasibuan (2001) bahwa "Disiplin harus ditegakkan dalam suatu organisasi perusahaan, karena tanpa dukungan disiplin karyawan yang baik sulit bagi perusahaan untuk mewujudkan tujuannya".

Dengan adanya disiplin kerja pada setiap karyawan yang ada di dalam perusahaan tersebut, akan menjadikan perusahaan itu menjadi maju. Karena setiap karyawan yang berdisiplin dalam melakukan pekerjaan dapat menyelesaikan tugas-tugas yang ada di dalam perusahaan tersebut walaupun tidak secara keseluruhan menghasilkan pekerjaan yang sempurna. Tetapi dalam jangka waktu tertentu karyawan akan melaksanakan pekerjaannya menjadi lebih baik.

Elemen lainnya yang masuk dalam kuadran A adalah Job Knowledge (pengetahuan atas pekerjaan) pengguna PKL mahasiswa Tata Boga Politeknik Negeri Balikpapan menganggap bahwa job knowledge salah satu indikator penting dalam kesusksesan mahasiswa Tata Boga bekerja di dunia perhotelan dan indutsri lainnya, namun pada fakta empiris element ini dinilai masih rendah oleh managemen hotel sebagai pengguna PKL.
Pengetahuan atas pekerjaan oleh karyawan adalah suatu keniscayaan dalam menghasilkan produk dan layanan jasa yang memuaskan kepada pelangagan. Ini juga ditegaskan oleh (Boella \& GossTurner, 2005, p.40-42) bahwa karyawan harus mempunyai pengetahuan yang memadai atas layanan yang disampaikan selain memahami semua fase atas pekerjaan yang dilakukan. Ini terjadi pada tiga bulan pertama, dimana belum adanya penjelasan secara rinci mengenai job description kepada mahasiswa oleh pembimbing dari Hotel.

Pada kuadran B (keep up the good work) adalah wilayah yang memuat faktor-faktor yang dianggap penting oleh pelanggan dan faktor-faktor yang dianggap oleh pelanggan sudah sesuai dengan yang dirasakannya sehingga tingkat kepuasannya relative lebih tinggi. Variabel-variabel yang masuk kuadran ini harus tetap dipertahankan karena semua variabel ini menjadikan produk/jasa tersebut unggul di mata pelanggan.

Ada 6 (enam) element yang masuk dalam kuadran ini yakni dependability, attitude, personality, quantity, adaptability, dan quality.Pengguna PKL atau management hotel telah memberikan kepercayaan kepada mahasiswa Tata Boga selama praktek untuk meng-handle atau bertanggungjawab terhadap satu pekerjaan dalam membuat produk setelah mengikuti PKL tiga bulan pertama. Ini membuktikan bahwa kemampuan pengetahuan tata boga yang didapatkan selama kuliah empat semester dinilai cukup berhasil. Ini sesuai dengan tingkatan pendidikan vokasi yakni D3, dimana lulusan siap bekerja. Selain itu, prodi Tata Boga dinilai telah mampu mensinergikan antara perkembangan mеnu industri dengan yang dipraktekan di kampus. Dengan kepercayaan yang telah diberikan tersebut maka akan terjalin interaksi/hubungan antara Politeinik Negeri Balikpapan dengan industri Hotel dan juga mahasiswa dengan karyawan.

Element yang dianggap berhasil oleh management hotel attitude (sikap) 
dimana mahasiswa PKL telah berusaha memberikan yang terbaik menghasilkan produk dan layanan jasa kepada pelanggan hotel sehingga menghasilkan produk yang berkualitas (Quality) mulai dari mempersiapkan, mengelola, hingga menjadi produk siap jual seperti pastry dan bakery, appetaizer, soup, dan main courses. Tidak hanya menghasilkan kualitas produk dan layanan jasa, mahasiswa Tata Boga juga dinilai mampu menghasilkan produk sesuai dengan tanggungjawab yang diberikan oleh atasan (pembimbing) selama PKL.

Ini sejalan dengan personality yang juga dinilai telah memberikan kepuasan kepada managemen hotel. Riset Ekinci dan Riley menunjukkan bahwa personality (kepribadian) yang harmonis adalah penting dalam proses layanan karena hal ini akan mempengaruhi kualitas layanan yang diberikan karyawan sehingga dapat mempengaruhi kepuasan pelanggan (Harris \& Fleming, 2005). Kondisi ini juga dipengaruhi oleh kecepatan mahasiswa Tata Boga dalam berdaptasi dengan lingkungan kerja (adaptability) yang dinilai memuaskan.Adaptability (adaptasi dengan lingkungan) atau mampu memberikan respon yang positif pada kebutuhan dan permintaan khusus dari pelanggan dalam proses layanan. (Zeithaml \& Bitner, 2003,).

Dari hasil penelitian, tidak ada element yang masuk dalam kuadran $\mathrm{C}$ (Low Priotiy) karena seluruh element dianggap penting oleh management hotel atau pengguna PKL mahasiswa Tata Boga, Politeknik Negeri Balikpapan.

Pada kuadran D Possible Overkill hanya ada satu element yang masuk dalam kategori yakni grooming. Management hotel menilai penampilan yang telah ditunjukan oleh mahasiswa PKL Tata Boga selama mengikuti PKL telah berpenampilan rapi dan bersih. Ini telah sesuai dengan kebijakan prodi Tata Boga yang telah mewajibkan seluruh mahasiswa menggunakan pakaian rapi saat mengikuti perkualiahan teori dan menggunakan baju praktek saat memasuki laboratorium restaurant, main kitchen dan pastry serta pantry. Sehingga pengguna layanan atau industri hotel menganggap hal tersebut tidak terlalu penting.

\section{Kesimpulan dan Saran}

Dari hasil pembahasan penelitian analisis kualitas layanan program praktek kerja lapangan mahasiswa jurusan Tata Boga Politeknik Negeri Balikpapan tahun 2015 di atas menunjukan bahwa kualitas layanan mahasiswa PKL Jurusan Tata Boga, Politeknik Negeri Balikpapan 2015 memuaskan untuk 9 atribut layanan yakni dependability, attitude, personality, Quantity, adaptability, Quality, Job Knowledgedan grooming yang memiliki rata rata penilaian minimal 3.2 (dalam kategori memuaskan). Sedangkan 3 atribut layanan lainnya attendance, iniciative, dandiscipline kurang memuaskan. Memiliki nilai yang cukup rendah atau dibawah 3.2 (dalam kategori memuaskan).

Ini sejalan dengan hasil analisi matrix IPA dimana terdapat empat element yang dianggap penting oleh managemen hotel namun belum memberikan kualitas layanan yakni attendance, iniciative, discipline dan job knowledge. Diperlukan upaya sistematis dan komprehensif dari managemen Poltekba Balikpapan secara umum dan prodi Tata Boga secara khusus, terutama dalam system pembelajaran praktek agar element kualitas layanan yang belum memberikan hasil maksimal dapat ditingkatkan pada mahasiswa PKL semester selanjutnya.

\section{Daftar Pustaka}

Boella, M., and Goss-Turner, S. (2005). Human resource management in the hospitality industry: An introductory guide. Amsterdam: Elsevier ButterworthHeinemann

Harris, E. G., and Fleming, D.E. (2005). Assesing the human element in service personality formation: personality 
congruency and the five factor model. The Journal of Services Marketing. Santa Barbara. Vol.19. Lss.4. 187.12 pgs.http://proquest.umi.com/pqdweb?did= 910970331\& sid $=10 \&$ Fmt $=4 \&$ clientId $=72$ $459 \& \mathrm{RQT}=309 \& \mathrm{VName}=\mathrm{PQD}$

Cahyono, Bambang Tri. 2004. Modul Manajemen Pemasaran. Badan Penerbit IPWI, Jakarta.

Fandi Tjiptono. 2001. Strategi Pemasaran. Edisi Revisi, Penerbit Andi Offset, Yogyakarta.

Fransisca Andreani (2007), Kualitas Layanan Trainee Program Manajemen Perhotelan Universitas Kristen Petra Pada Industri Hotel Berbintang Lima Di Surabaya, Jurnal Manajemen Perhotelan, vol.3, no.2, September 2007: 57-69

Gronroos, C. (2000). Service management and marketing: A customer relationship management approach. 2nd edn. Chichester:

Husein Umar, 1999. Metode Penelitian Aplikasi Dalam Pemasaran, PT. Gramedia Pustaka Utama, Jakarta

J. Supranto, 2001. Pengukuran Tingkat Kepuasan Pelanggan Untuk Manaikkan Pangsa Pasar,

Kotler Philip. 2003, Marketing Management. 11th Edition, Pearson Education Internatoral

King, Jr., John H. and Ronald F. C. (2006).Managing for quality in the hospitality industry. New Jersey: Pearson Education, Inc.

Lupiyoadi, Rambat. 2001. Manajemen Pemasaran Jasa. Edisi Pertama. Salemba Empat: Jakarta
Lupiyoadi, Rambat. 2001. Manajemen Pemasaran Jasa. Salemba Empat, Jakarta Lovelock, C., and Wirtz, J. (2004). Services marketing: People, technology, strategy. 5thedn. New Jersey: Pearson Prentice Hall.

Mc Carthy, E. Jerome \& William D Perreault, Jr, 2004. Intisari Pemasaran : Sebuah Ancangan

Manajerial Global, Edisi Ke-6, Jilid 1 (terjemah), Bina Rupa Aksara, Jakarta.

Malayu P Hasibuan, 2007. Managemen Sumber Daya Manusia, Bumi Aksara Jakarta

Payne, Andrian, 2001, The Esseence Of Service Marketing/ alih Bahasa: Fandy Tjiptono, Penerbit Andi, Yogyakarta.

Ratminto dan Atik Winarsih. 2005. Manajemen Pelayanan. Pustaka Pelajar: Yogyakarta

Rineke Cipta, Jakarta 2002. MetodeRiset: Aplikasinya Dalam Pemasaran, Rineke Cipta, Jakarta

Supranto. 2006. Pengukuran Tingkat Kepuasan Pelanggan. Cetakan Ketiga. Rineka Cipta: Jakarta

Vincent Garpersz. 2005, Manajemen Bisnis Total Dalam Era Globalisasi. PT. Gramedia, Jakarta

Yoeti, H. Oka A, 2003. Manajemen Pemasaran Hotel, PT Perca, Jakarta.

Zeithaml, V. A., and Bitner, M. J. (2003). Service marketing: Integrating customer focus across the firm. International Edition. New York:The McGraw-Hill Companies. Inc. 